\title{
Mechanical Strengths of Sawdust-Ash-Admixed Gum Arabic Concrete
}

\author{
Augustine U. Elinwa \\ Civil Engineering Department, Abubakar Tafawa Balewa University, \\ PMB 0248 Bauchi, Bauchi State, Nigeria \\ * Corresponding author email: auelinwa@gmail.com
}

Received: 13 December 2020 / Revised: 27 March 2021 / Accepted: 20 May 2021 / Published: 03 June 2021

\begin{abstract}
Gum Arabic and sawdust ash were used both as an emulsifier admixture and supplementary cement material to address some of the gaps between pozzolanic and conventional concretes. Four concrete mixtures of 1: 2.24: 2.71 , with a water-cement ratio of 0.5 , and cement content of $370 \mathrm{~kg} / \mathrm{m}^{3}$, was used. The concrete mixtures were designated as M-00, M-00GA, M-10GAS, and M-30GAS, signifying the control, control with gum Arabic (GA), and mix with both gum Arabic and sawdust ash (GAS), respectively. The dosage was $0.5 \%$ of GA and the SDA replacement by wt. $\%$ was at $10 \%$ and $30 \%$, respectively. The concrete samples were cured for 90 days, and tested for mechanical strengths. The results showed that adding GA alone to concrete mixture improved the mechanical strengths of the concrete and the gum Arabic acted like an accelerator. When both GA and SDA were used together in the dosage of $0.5 \%$ with $10 \%$ and $30 \%$ proportions respectively, the mechanical strengths of the concrete decreased. The findings also reported that the two-third strength ratio at 28 -days of curing which is used for the conventional concrete in stripping the formwork, may not be appropriate for use on pozzolanic concrete. This is because of the delay in setting times and thus, attaining the required design strength. Therefore, it is proposed to be taken at an age beyond 28 days of curing to carter for the pozzolanic effects which starts well above 28 -days.
\end{abstract}

Keywords: Gum Arabic concrete; mechanical strengths; two-third strength ratio; statistical parameters

\section{Introduction}

Concrete is the most widely used building material in the world because of variety and durability. To continue to be relevant ideas are growing on how to make concrete more attractive and less cost implicative because of the environmental and energy issues surrounding it. These have given the need for attentions to be turned to low-impact materials for which sawdust and gum Arabic can conveniently be classified. The reasons are, they are readily available as wastes or natural occurring materials. However, some of the setbacks using some of these low-impact material are mostly that of durability issues. Efforts are geared towards applying technology to improve the processes and upgrade the material, and proper documentations of such methods that will minimize the variability associated with these materials.

The effects of the addition of gum Arabic powder (GA) to concrete was studied by Elinwa and Umar [1] using x-ray diffraction and microstructure methods of applications. The GA dosage was from $0.00 \%$ to $1.00 \%$, at the intervals of 0.25 by wt. $\%$ of cement. The mix ratio was $1: 1.7: 2.5$ with w/c of 0.5 , and comprised of five mixes (M-00 - M-04) that were used to prepare cube concrete specimens that were cured for 28 days before testing to failure. Some of the conclusions derived from the work are the potencies of gum Arabic in improving concrete mixture properties because of the emulsifying effects. The hydration products (microstructure) of the samples showed that compound like Wollastonite, Tobermorite etc. enhanced the compressive strength [2], and best performance was at $0.5 \%$ dosage [3]. However, the water absorption and porosity of the concrete mixture increased, and the use of a water reducing plasticizer was advocated.

Copyright (C) 2021. The Author(s). Published by AIJR Publisher.

This is an open access article under Creative Commons Attribution-NonCommercial 4.0 International (CC BY-NC 4.0) license, which permits any non-commercial use, distribution, adaptation, and reproduction in any medium, as long as the original work is properly cited. 
Mechanical Strengths of Sawdust-Ash-Admixed Gum Arabic Concrete

Sawdust ash as a supplementary material for cement mortar and concrete, was used, after burning sawdust (open method), grinding and sieving, through a sieve size of $212 \mu \mathrm{m}$, and used in proportions of $0 \%$ to 30 $\%$ to produce concrete cube samples that were cured for 28 days before testing to failure to obtain the compressive strength and other concrete parameters [4]. They concluded that SDA has retarding properties, and it delays the setting times of concrete. It was also shown in the same investigation that it is a pozzolana. However, their work showed that compressive strength decreased as the percentage replacement increased, and the optimum replacement was at $10 \%$ by wt. \% of cement. This finding has also been collaborated by other researchers on timber ash [5]. SDA has a high affinity for water. In other works carried out using SDA, it was established through series of confirmation tests that it is adequate as powder material for selfcompacting concrete (SCC). At a w/c ratios of 0.4 and 0.42 , and at dosages of naphthalene sulfonate superplaticizers of $3.5 \%$ and $2 \%$, respectively, there was compatibility between the powder material (SDA) and cement at an optimum replacement of $10 \%$. Elinwa and Abdulkadir [6] used SDA as an inhibitor for reinforcement corrosion. It was concluded in this work that at $10 \%$ SDA replacement corrosion was minimal. The use of GA and SDA together for concrete production is built on the fact that both of them have been classified as low-impact materials and thus, have their individual setbacks. The use of GA in concrete was observed to increase water absorption and porosity, and also increased the compressive strength [1]. On the other hand, the use of SDA, a supplementary cementing material, decreased the compressive strength of concrete, and also decreased water absorption. The thrust of this investigation therefore, is to exploit the benefits of the characteristics of these two materials, using the GA as an admixture while the SDA serves as a mineral admixture for the improvement of the concrete mixtures. Thus, the first phase of the research would use SDA at $0 \%, 10 \%$ and $30 \%$ to replace cement by wt. $\%$, and to which $0.5 \%$ GA by wt. $\%$ of cement, will be added. The $0.5 \%$ was the established optimum from previous works on GA [1]. Both SDA and GA were used to possibly address the cases of water absorption in GA-concrete and low compressive strength in SDA-concrete, respectively. The second phase would be to establish particular effects of the combined effects of SDA and GA on the mechanical strengths of SDAGA concrete, using statistical principles in Minitab 18 software. They will be used for confirmations on the quality of the concrete parameters.

\section{Materials}

'Dangote' brand of Portland cement Type Grade 43 was used throughout the investigation and the cement conformed to BS EN 196 part 3 [7]. The physical and chemical properties of the cement are shown in Table 1 . The fine aggregate is a river sand and has a specific gravity of 2.61 , moisture content, $0.36 \%$, bulk density of $1485 \mathrm{~kg} / \mathrm{m}^{3}$, and a fineness modulus of 2.4 . The coarse aggregate is crushed and angular in shape with a maximum size of $20 \mathrm{~mm}$. It has a specific gravity of 2.65 , moisture content, $0.17 \%$, aggregate impact value (AIV) of $8.5 \%$ and aggregate crushing value of $12.2 \%$. Both the fine and coarse aggregate are free from deleterious substances, and tested in accordance with BS EN: 1097-6 [8]. The sieve analysis of the fine and coarse aggregates are shown in Tables 2 and 3.

Table 1: Physical and Chemical Properties of Dangote Portland Cement

\begin{tabular}{lc}
\hline Specific gravity & 3.15 \\
\hline Loose bulk density $\left(\mathrm{kg} / \mathrm{m}^{3}\right)$ & 3150 \\
\hline Fineness modulus & $<10$ \\
\hline & \\
\hline Oxide & Chemical properties \\
\hline $\mathrm{CaO}$ & Percentage by weight \\
\hline $\mathrm{SiO}_{2}$ & 62 \\
\hline $\mathrm{Al}_{2} \mathrm{O}_{3}$ & 17 \\
\hline $\mathrm{Fe}_{2} \mathrm{O}_{3}$ & 3.0 \\
\hline $\mathrm{MgO} \mathrm{O}$ & 0.5 \\
\hline $\mathrm{Na}_{2} \mathrm{O}$ and $\mathrm{K}_{2} \mathrm{O}$ & 2.0 \\
\hline $\mathrm{SO}_{3}$ & 0.6 \\
\hline
\end{tabular}


Augustine U. Elinwa, J. Mod. Mater.; Vol. 8, Issue 1, pp: 12-29, 2021

Table 2: Sieve Analysis of Fine Aggregate

\begin{tabular}{lc}
\hline Sieve size & $\%$ mass passing \\
\hline $3.35 \mathrm{~mm}$ & 99.7 \\
\hline $2.00 \mathrm{~mm}$ & 98.3 \\
\hline $1.18 \mathrm{~mm}$ & 93.7 \\
\hline $600 \mathrm{micron}$ & 73.9 \\
\hline $425 \mathrm{micon}$ & 49.9 \\
\hline 300 micron & 21.9 \\
\hline 212 micron & 3.3 \\
\hline 150 micron & 1.1 \\
\hline 75 micron & 0.5 \\
\hline Pan & 0.0 \\
\hline
\end{tabular}

Table 3: Sieve Analysis of Coarse Aggregates

\begin{tabular}{lc}
\hline Sieve size $(\mathrm{mm})$ & Percentage passing $(\%)$ \\
\hline 28 & 100 \\
\hline 20 & 91.3 \\
\hline 14 & 33.0 \\
\hline 10 & 13.0 \\
\hline 6.3 & 3.3 \\
\hline 5.0 & 2.0 \\
\hline Pan & 0.0 \\
\hline
\end{tabular}

\subsection{Sawdust ash}

The sawdust used for the production of the sawdust ash (SDA) was obtained from a timber wastes located where timber woods are sold in the local market and processed in the kiln at ceramic section of Industrial Design Department, Abubakar Tafawa Balewa University Bauchi. The sawdust ash (SDA) was obtained by incineration of sawdust at a temperature between $400^{\circ} \mathrm{C}$ to $600^{\circ} \mathrm{C}$, under a control burning system. The ash was allowed to cool for 2 hours before sieving through sieve of $150 \mu \mathrm{m}$. The SDA has specific gravity, and moisture content of 2.16, and 0.24 respectively. Table 4 shows the chemical properties of the sawdust ash (Present) and wood waste ash $[9,10]$. The methods of burning were not very clearly stated in their works. The wood wastes were presumably burnt with the bark, and one [9] was collected from a boiler and the other [10] was burnt at $500^{\circ} \mathrm{C}$. However, the LOI shows good burning. The SDA used in the present study has almost the same silica content with $[9,10]$, but relatively low values of $\mathrm{Al}_{2} \mathrm{O}_{3}$ and $\mathrm{Fe}_{2} \mathrm{O}_{3}$ compared with $[9,10]$, but with a higher $\mathrm{K}_{2} \mathrm{O}$ of $11.57 \%$. However, all satisfied the $70 \%$ minimum of $\mathrm{SiO}_{2}+\mathrm{Al}_{2} \mathrm{O}_{3}+$ $\mathrm{Fe}_{2} \mathrm{O}_{3}$ as required for the definition of a pozzolana by ASTM C-618.

Table 4: Chemical composition of sawdust ash

\section{Percentage Oxide Composition}

\begin{tabular}{clccc}
$\mathbf{S} / \mathbf{N}$ & $\begin{array}{l}\text { Chemical } \\
\text { Composition }\end{array}$ & Present & Siddique et al [9] & Raza et al. [10] \\
\hline $\mathbf{1}$ & $\mathrm{CaO}$ & 9.9 & 1.96 & 2.07 \\
\hline $\mathbf{2}$ & $\mathrm{SiO}_{2}$ & 63.42 & 64.58 & 65.77 \\
\hline $\mathbf{3}$ & $\mathrm{Al}_{2} \mathrm{O}_{3}$ & 4.11 & 17.11 & 5.26 \\
\hline $\mathbf{4}$ & $\mathrm{Fe}_{2} \mathrm{O}_{3}$ & 2.26 & 11.24 & 9.60 \\
\hline $\mathbf{5}$ & $\mathrm{MgO}$ & 5.8 & 1.98 & 4.10 \\
\hline $\mathbf{6}$ & $\mathrm{Na}_{2} \mathrm{O}$ & 0.04 & - & 0.07 \\
\hline $\mathbf{7}$ & $\mathrm{SO}_{3}$ & - & - & 1.08 \\
\hline $\mathbf{8}$ & $\mathrm{K}_{2} \mathrm{O}$ & 11.57 & 2.12 & 2.47 \\
\hline $\mathbf{9}$ & $\mathrm{LOI}$ & 4.67 & 5.0 & 4.33 \\
\hline
\end{tabular}


Mechanical Strengths of Sawdust-Ash-Admixed Gum Arabic Concrete

\subsection{Gum Arabic}

Gum Arabic is a normal branched-chain multi-functional hydrocolloid with a complex of calcium, magnesium, and potassium that is strongly neutral or mildly acidic, arabinogalactan- proteins. The gum Arabic (Acacia Senegal) was obtained locally from the local market, and was finely grounded and sieved through sieve size 300 micron to remove impurities [1]. Then after, 1000g was measured and placed in a beaker and to which 1 litre of hot water was added and stirred gently to ensure that it entirely dissolves properly in the solution. After the entire sample was dissolved, a reasonable quantity of water was added to the solution to get its viscosity to the desired state. Finally the entire solution was properly stirred to ensure a thorough mixture. The physical and chemical composition of the gum Arabic is shown in Table 5.

Table 5: Physical and Chemical Composition of Gum Arabic

\begin{tabular}{lc}
\hline Odor & Odorless \\
Appearance & glassy \\
$\mathrm{pH}$ & 4.5 \\
Emulsifying properties & $30 \%$ \\
Solubility (in water) & $43-48 \%$ \\
Density & $1.35-1.49$ \\
\hline & \\
\hline Element & \\
\hline Potassium & Chemicals \\
\hline Sodium & 25 \\
\hline Magnesium & 17.3 \\
\hline Calcium & 35.56 \\
\hline Manganese & 29.36 \\
\hline Copper & 1.1 \\
\hline Zinc & 0.022 \\
\hline Iron & 0.025 \\
\hline
\end{tabular}

\section{Experiment}

The experiments on the fresh and hardened concrete were carried out using a mix proportion of 1: 2.24: 2.71 with a cement content of $370 \mathrm{~kg} / \mathrm{m}^{3}$ and water-cement ratio of 0.5 . Four mixes designated as M- 00 , M-00/0.5GA, M-10SDA/0.5GA, and M-30SDA/0.5GA, were used in this work. Mix M-00 is the control (without GA or SDA). The other mixes contain both GA and SDA in various proportions respectively. These are used to assess the effects of SDA and GA, on the cement mortar, and other mechanical strengths (compressive strength of flexural and splitting tensile test), as the case may be. The tests on the compressive strength was carried in accordance to ASTM C31/C31 M-19a [11] using a cube mold size of $100 \mathrm{~mm}$. A total of sixty specimens were cast and cured at the laboratory temperature in a water tank for a period of 90 days. At the end of each curing regime three of the samples were tested to failure using the compressive testing machine model of $2000 \mathrm{kN}$ capacity, and the average recorded. The flexural and splitting tensile tests were carried out independently, using beam dimensions of $100 \mathrm{~mm} \times 100 \mathrm{~mm}$ x $500 \mathrm{~mm}$, and cylindrical molds of $150 \mathrm{~mm} \times 300 \mathrm{~mm}$ dimensions, conforming to BS EN-12390-5 [12], and ASTM C78/C78M [13]. One hundred and twenty (120) specimens were cast, sixty (60) each for each test, and cured for 90 days before testing to failure. Three specimens for each curing regime were tested and the average recorded. The results of the compressive, flexural and splitting tensile tests are given in Table 6. 
Augustine U. Elinwa, J. Mod. Mater.; Vol. 8, Issue 1, pp: 12-29, 2021

Table 6: Mechanical Strength of SDA-GA Concrete

\begin{tabular}{clccccc}
\hline & & \multicolumn{5}{c}{ Age (days) } \\
\cline { 2 - 7 } Property & Mix No & 3 & 7 & 28 & 60 & 90 \\
\hline \multirow{3}{*}{ Compressive strength } & M-00SDA/GA & 17.9 & 19.2 & 26.7 & 27.4 & 28.0 \\
$\left(\mathrm{kN} / \mathrm{m}^{2}\right)$ & M-00SDA/0.5GA & 20.2 & 23.5 & 28.6 & 28.8 & 29.2 \\
& M-10SDA/0.5GA & 13.6 & 14.3 & 18.3 & 23.1 & 19.7 \\
& M-30SDA/0.5GA & 9.3 & 10.6 & 11.1 & 13.4 & 13.6 \\
\hline \multirow{3}{*}{ Flexural strength } & M-00SDA/GA & 4.8 & 5.0 & 5.2 & 5.2 & 5.3 \\
$\left(\mathrm{kN} / \mathrm{m}^{2}\right)$ & M-00SDA/0.5GA & 4.9 & 5.2 & 5.2 & 5.3 & 5.3 \\
& M-10SDA/0.5GA & 4.8 & 4.8 & 4.9 & 5.1 & 5.2 \\
& M-30SDA/0.5GA & 3.6 & 4.3 & 4.4 & 4.8 & 4.8 \\
\hline \multirow{2}{*}{ Splitting tensile } & M-00SDA/GA & 1.0 & 1.2 & 1.9 & 1.9 & 2.0 \\
$\left(\mathrm{kN} / \mathrm{m}^{2}\right)$ & M-00SDA/0.5GA & 1.6 & 1.8 & 2.0 & 2.3 & 2.4 \\
& M-10SDA/0.5GA & 1.1 & 1.1 & 1.5 & 1.7 & 1.8 \\
& M-30SDA/0.5GA & 0.7 & 0.9 & 1.2 & 1.3 & 1.6 \\
\hline
\end{tabular}

\section{Results and Discussion}

Figure 1 (a, b, \& c) shows the effect of gum Arabic alone on concrete strength. Adding GA to concrete mixture minimally improved the mechanical strengths (compressive strength, flexural and splitting tensile) of concrete. This finding further confirms an earlier report by Elinwa and Umar, [1]. C.Zhao et al [14] and R.Mbugua et al [15], respectively made the same confirmation. The percentage differences in the mechanical strengths of GA-concrete show that the increase for compressive strength ranged from $4.3 \%$ to $12.9 \%$, the flexural strength from $0.0 \%$ to $4.0 \%$, and splitting tensile strength from $5.3 \%$ to $60 \%$. A particular trend in the development of strength (formation of C-S-H) was observed. There was an early strength gain of approximately $31 \%, 20 \%$ and $2 \%$, for 3, 7, and 28 days respectively. This indicates that the GA may be used as an accelerator, whose characteristics is the development of higher hydration at early ages. Thus, this observation negates the earlier findings of Elinwa and Umar [1] working on the same GA-concrete. There GA was classified as a retarder which has the characteristics of slowing down the hydration process. With this observed discrepancies in mind more researches on the behavior of GA as an admixture with concrete for proper characterization is important. A maximum dosage of $0.9 \%$ and an increase of about 8 $\%$ above the control mix have been reported on compressive strength [16]. Equally reported is the use of cassava starch as an emulsifier with the addition of 0.75 by wt. $\%$ of cement of naphthalene sulfonate. A maximum dosage of $0.8 \mathrm{wt} . \%$ by cement gave the maximum strength cured for 90 days [17].

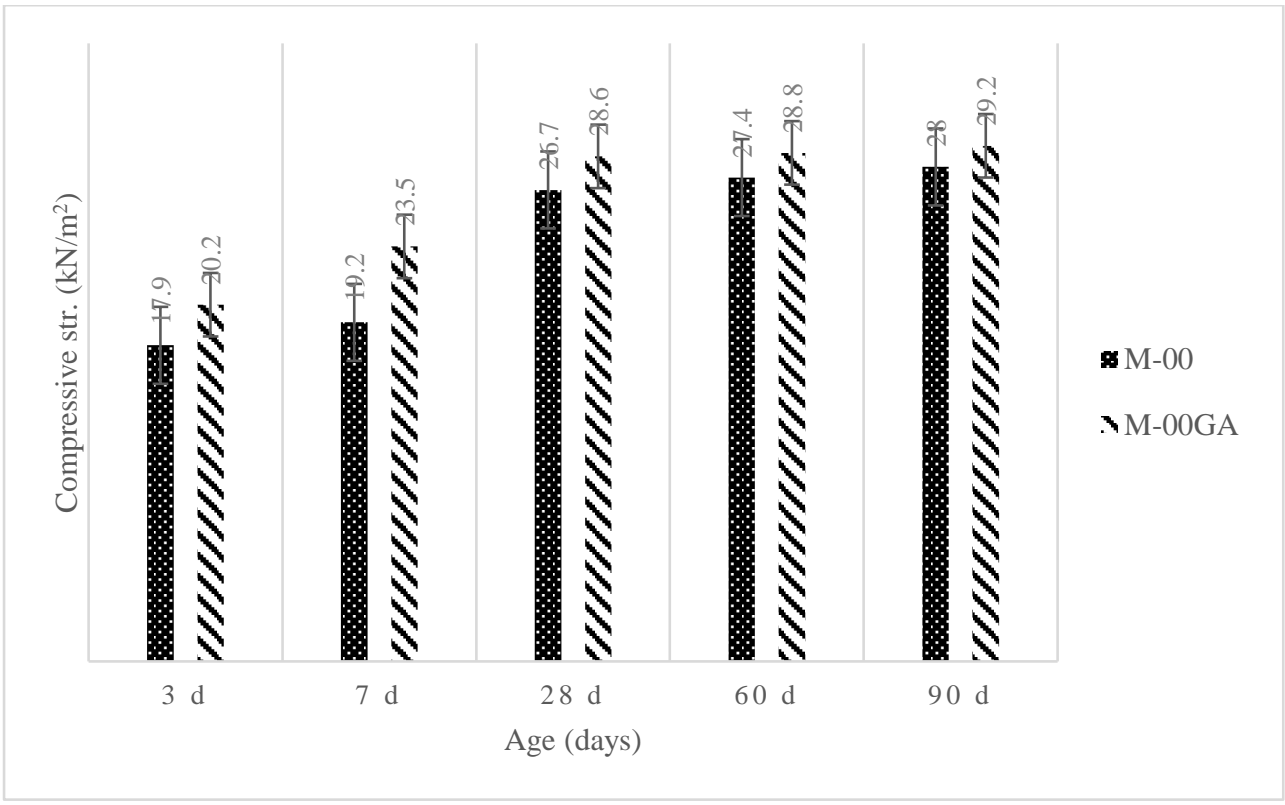

(a) 


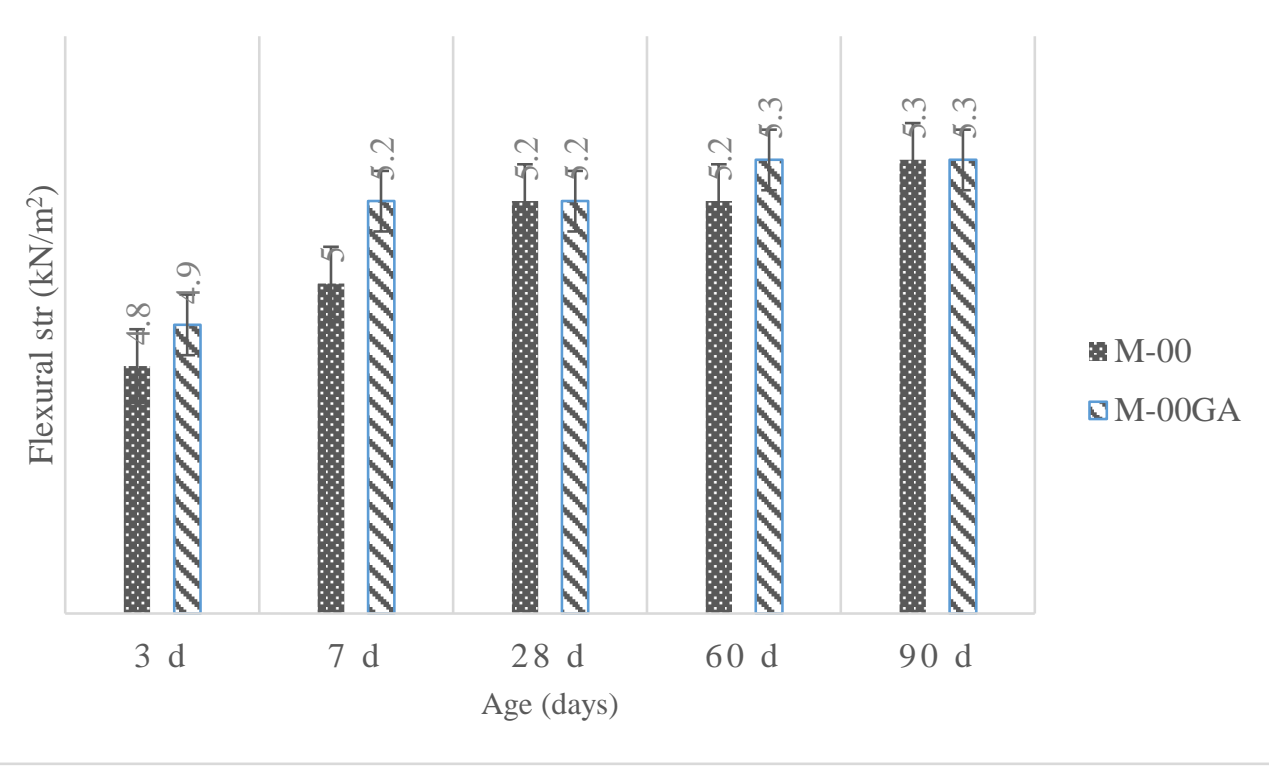

(b)

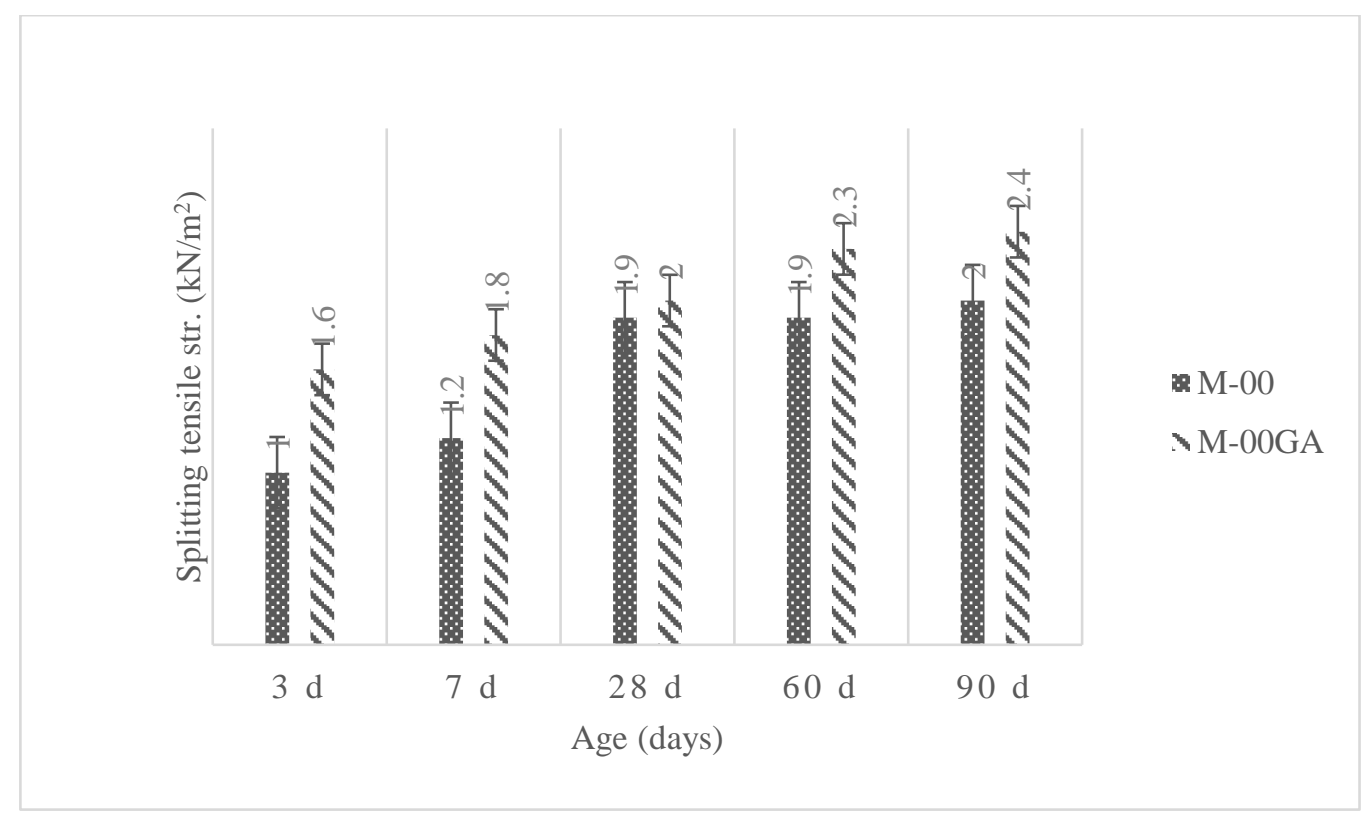

(c)

Figure 1: Effect of Gum Arabic

Table 7: Seven-Twenty Eight Day Strength (K) of Concrete

\begin{tabular}{ccccc}
\hline \multirow{2}{*}{ Mix No } & \multicolumn{4}{c}{ K-strength ratio (\%) } \\
\cline { 2 - 5 } M-00SDA/GA & $28 \mathrm{~d}$ & $60 \mathrm{~d}$ & $90 \mathrm{~d}$ & Average \\
\hline M-10SDA/0.5GA & 72 & 70 & 69 & 70 \\
\hline
\end{tabular}

The second phase of this work is evaluating the effect of addition of SDA to the mix with GA on the mechanical strengths. These effects are shown in Figure $2(\mathrm{a}, \mathrm{b}, \mathrm{dc})$, and show decrease in mechanical strengths (Compressive, flexural and splitting tensile). Therefore, the addition of SDA lowers the mechanical strengths of concrete. Many factors have been attributed to lower strengths in concrete when SDA is used. Apart from being a weak pozzolana, cement-SDA particle flocculation and hydration reactions 
Augustine U. Elinwa, J. Mod. Mater.; Vol. 8, Issue 1, pp: 12-29, 2021

may be one of the main factors for low strength recorded with SDA [18]. It is therefore suggested that the use of plasticizer GA-concrete maybe required for strength improvement.

The strength ratios for the compressive strength is shown in Table 7 . This is $78 \%$ for M-10SDA/0.5GA and is higher than that stipulated by the code of practice for conventional concrete which is two-third of 28 days strength $(67 \%)$. This strength is important for stripping of the formwork, and must be satisfied for all the concrete mixes. Although the $67 \%$ has been satisfied for all the mixes, however, the minimum design strength for SDA-GA concrete of $20 \mathrm{kN} / \mathrm{m}^{2}$ (Design strength) has not been satisfied for mixes M10SDA/0.5GA $\left(18.3 \mathrm{kN} / \mathrm{m}^{2}\right)$, and M-30SDA/0.5GA $\left(11.1 \mathrm{kN} / \mathrm{m}^{2}\right)$ at 28 days. The $67 \%$ minimum required is only satisfied at 60 days $(23 \mathrm{kN})$ and marginally at 90 days $(20 \mathrm{kN})$ respectively. Since SDA (Pozzolanic) is not a conventional material, and because of delayed hydration exhibited by SDA, this study proposes using the $60^{\text {th }}$ day strength for the evaluation of this property. This applies only to the compressive strength which is for formwork stripping. At 60 days, both the minimum strength $(20 \mathrm{kN})$ and two-third strength are both satisfied. Therefore, for concretes containing cement replacement or addition materials the traditional norms of 7-28 days strength of $67 \%$ may not be a realistic resolution. It is therefore recommended to consider this strength ratio indicator at the 7-60 days. This is because of the delay in setting time due to the pozzolanic nature of the SDA.

Table 8 shows the flexural-compressive strength, splitting tensile-compressive strength, and splitting tensile-flexural strengths ratios $\left(\mathrm{k}_{2}, \mathrm{k}_{3}, \mathrm{k}_{4}\right)$. At the ages of 28 days, 60 days and 90 days, the flexuralcompressive strength ratios are $27 \%, 22 \%$ and $26 \%$, respectively, for 10SDA/0.5GA. Elinwa and Kabir who worked with spent foundry sand (SFS) and hospital waste ash (HWA), which are pozzolanic in nature, gave the strength-ratios as 0.31 and 0.18 , respectively, for flexural-compressive strength [19, 20]. The studies on flexural strength in the design of reinforced concrete is very important because an accurate estimation of the relation of tensile strength to compressive strength is needed for proper structural design [21]. It has also been argued that the present standards do not take into consideration material constituent characteristics in the formulation of the standards such as blended cements [19]. However for tensile tests (direct or indirect), the splitting test of the cylindrical specimen gives a more reasonable tensile strength estimation than the direct tensile test or the modulus of rupture test. The splitting tensile-compressive ratio for this work at the ages of 28 days, 60 days, and 90 days are $8 \%, 7 \%$ and $9 \%$, while, the splitting tensile and flexural strength ratio are $37 \%, 33 \%, 35 \%$, respectively. More data on pozzolanic materials on this effect are required for confirmation.

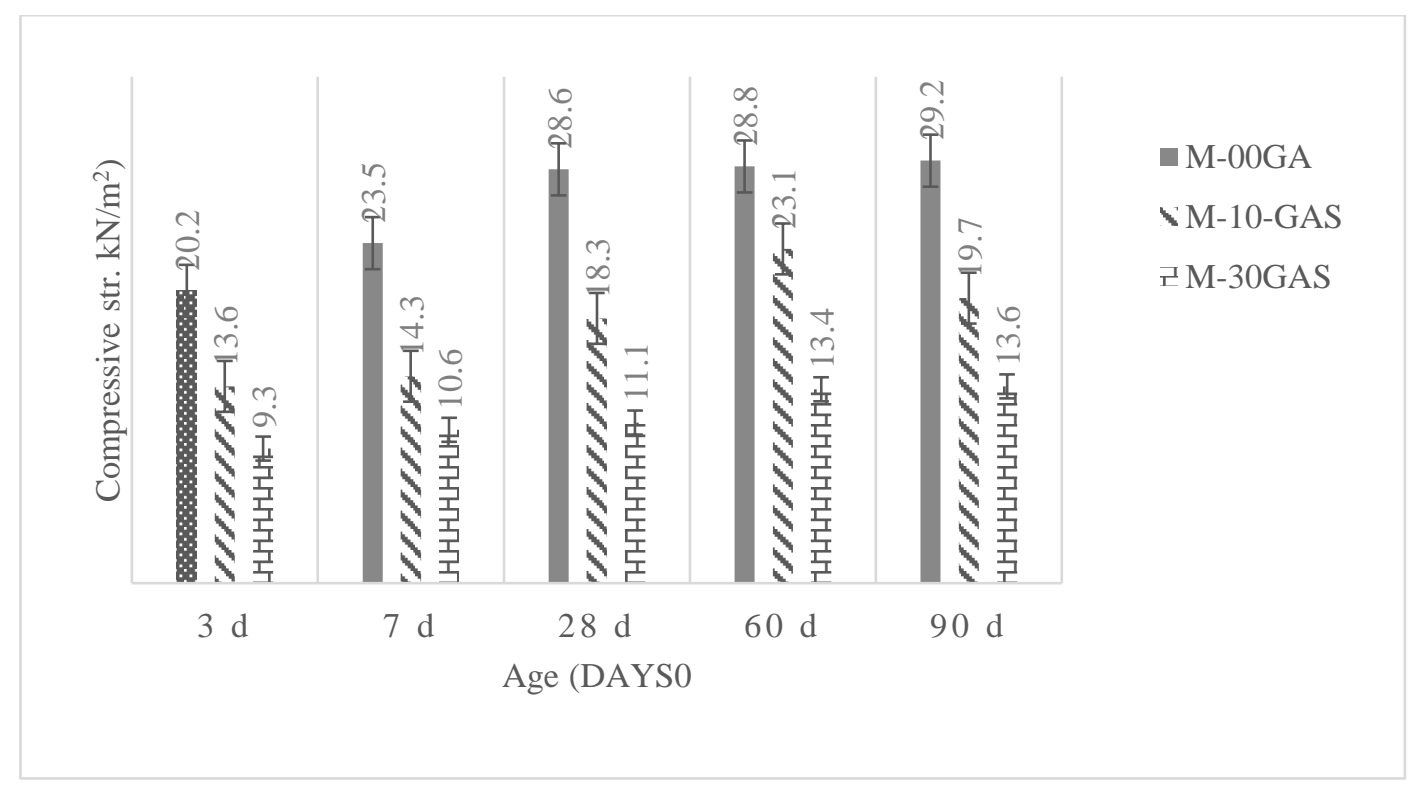

(a) 


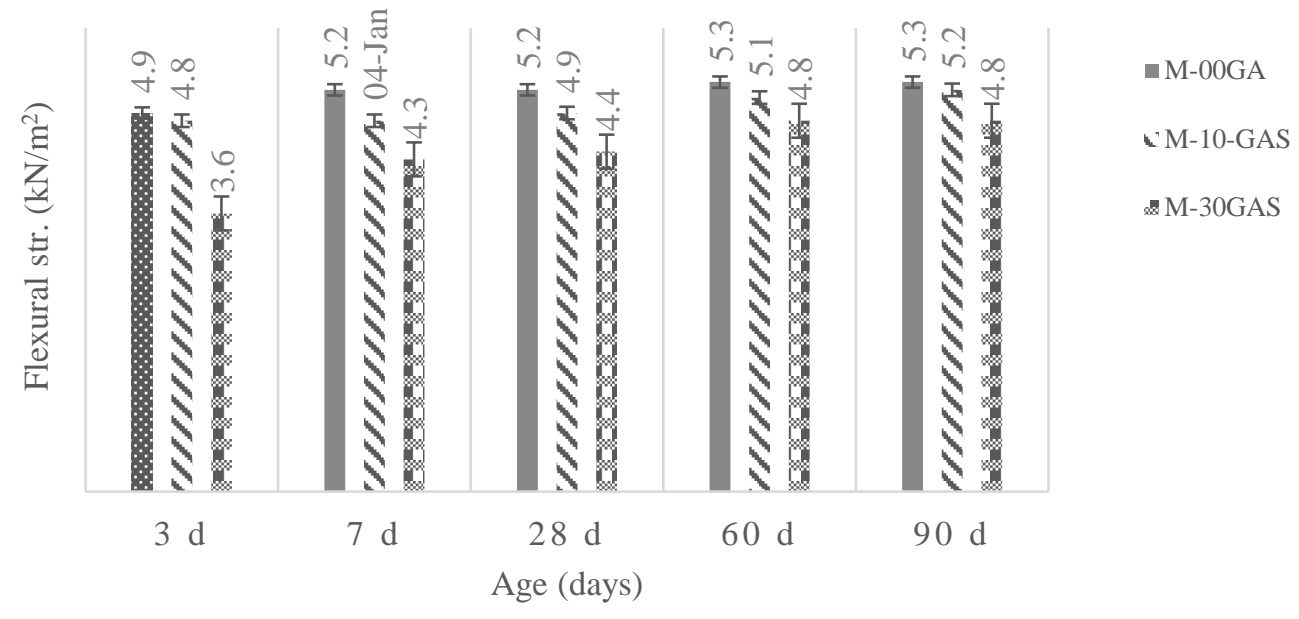

(b)

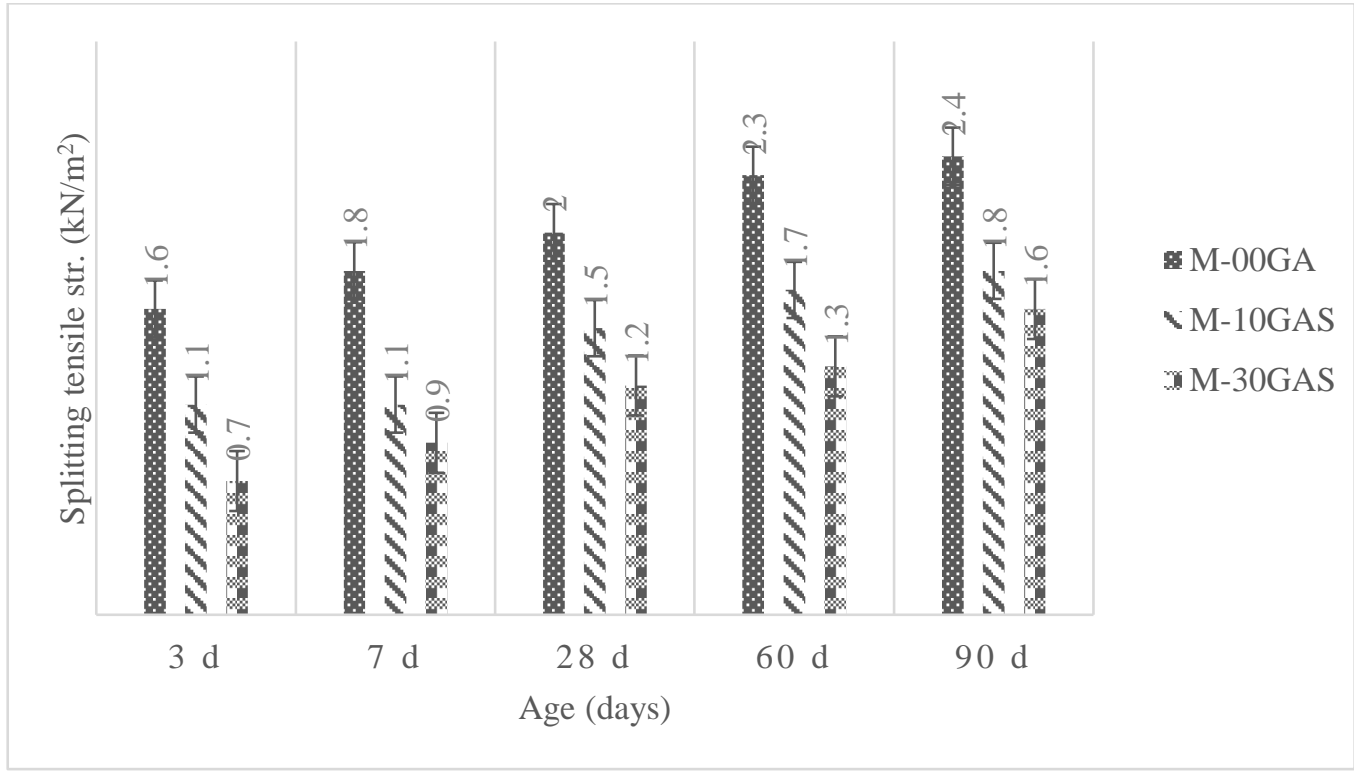

(c)

Figure 2: Effect of SDA-GA

Table 8: Mechanical Strength Ratios ( $k$ ) of SDA-GA Concrete

Age Ratio (\%)

\begin{tabular}{lrrrr}
\cline { 2 - 5 } Parameter & $28 \mathrm{~d}$ & $60 \mathrm{~d}$ & $90 \mathrm{~d}$ & Average \\
\hline Flexure-Compressive $\mathbf{f}_{\mathbf{r}} / \mathbf{f}_{\mathbf{c}}\left(\mathbf{k}_{\mathbf{2}}\right)$ & 27 & 22 & 26 & 25 \\
\hline Splitting Tensile-Compressive $\mathbf{f}_{\mathbf{t}} / \mathbf{f}_{\mathbf{c}}\left(\mathbf{k}_{\mathbf{3})}\right.$ & 8 & 7 & 9 & 8 \\
\hline Splitting Tensile-Flexure $\mathbf{f}_{\mathbf{t}} / \mathbf{f}_{\mathbf{r}}\left(\mathbf{k}_{\mathbf{4}}\right)$ & 37 & 33 & 35 & 35 \\
\hline
\end{tabular}




\subsection{X-Ray Diffraction Analysis of Concrete Samples}

The X-Ray Diffraction analysis was carried out at the National Steel Council, Kaduna, Nigeria, using crushed samples of the cube compressive strength test results, with mixes containing M-00 SDA/GA as control, M-00SDA/0.5GA, M-10SDA/0.5GA, and M-30SDA/0.5GA, respectively, at 28 days of age. The samples were oven dried at $60^{\circ} \mathrm{C}$ for thirty minutes to remove the moisture, grinded, and sieved in powdered form using sieve size $0.15 \mu \mathrm{m}$.The XRD equipment used is the Schimadzu 600 Model machine and tested in accordance with ASTM D3906-03 [22]. The diffractogrammes of the XRD at various angles of 2Theta are shown in Figures 3 to 6.

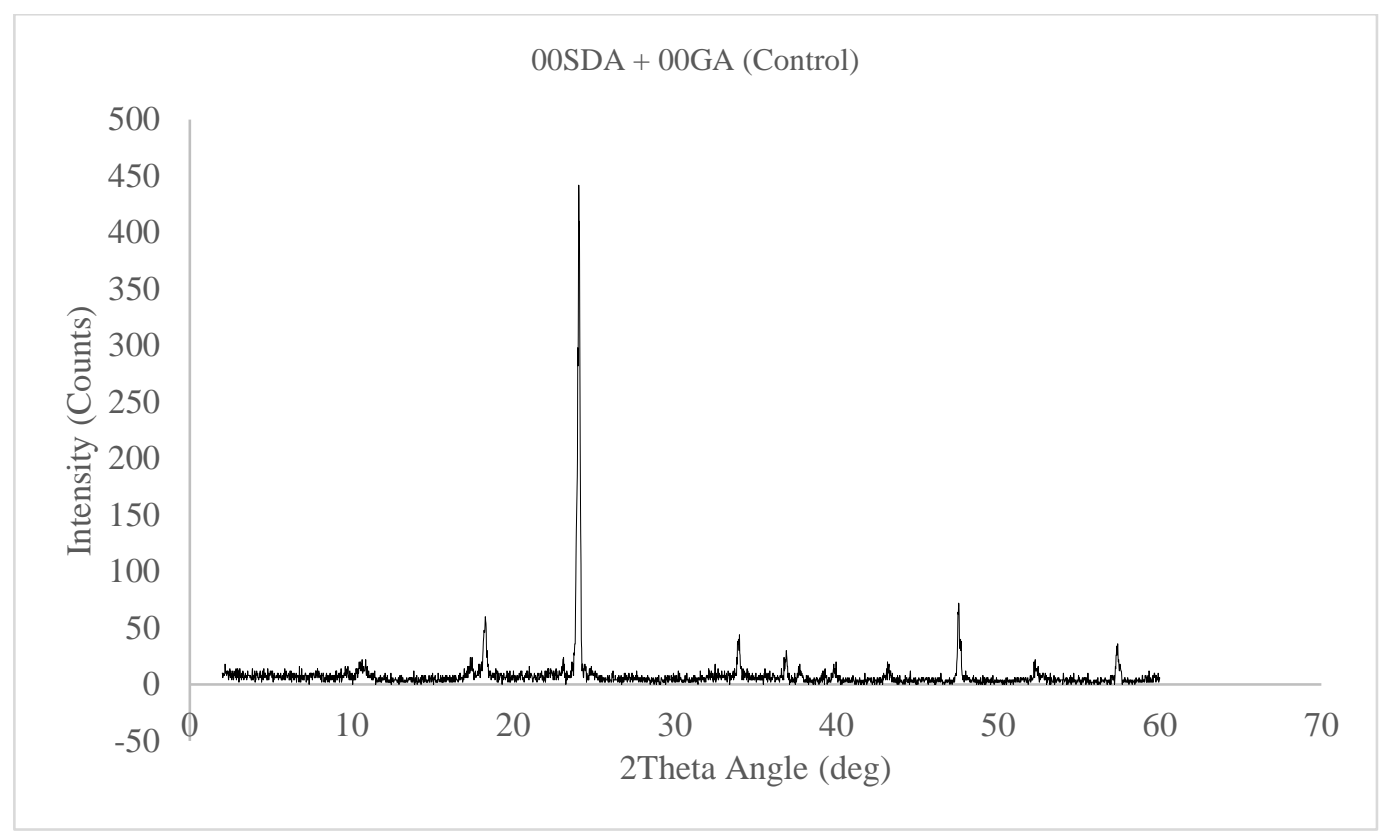

Figure 3: X-Ray Diffractogramme of Control Concrete (M-OOSDA/GA)

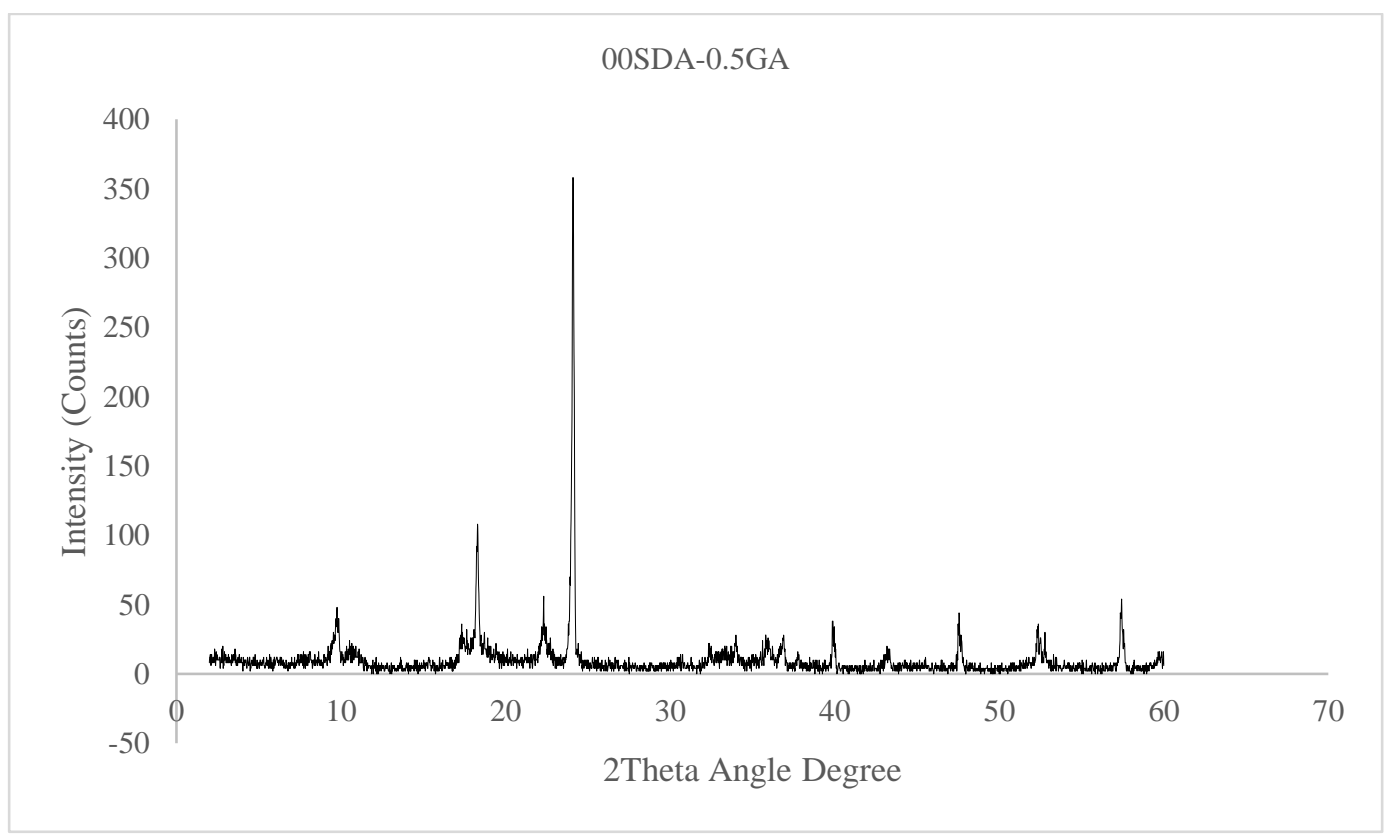

Figure 4: X-Ray Diffractogramme of Concrete and Gum Arabic (M-00SDA/0.5GA) 


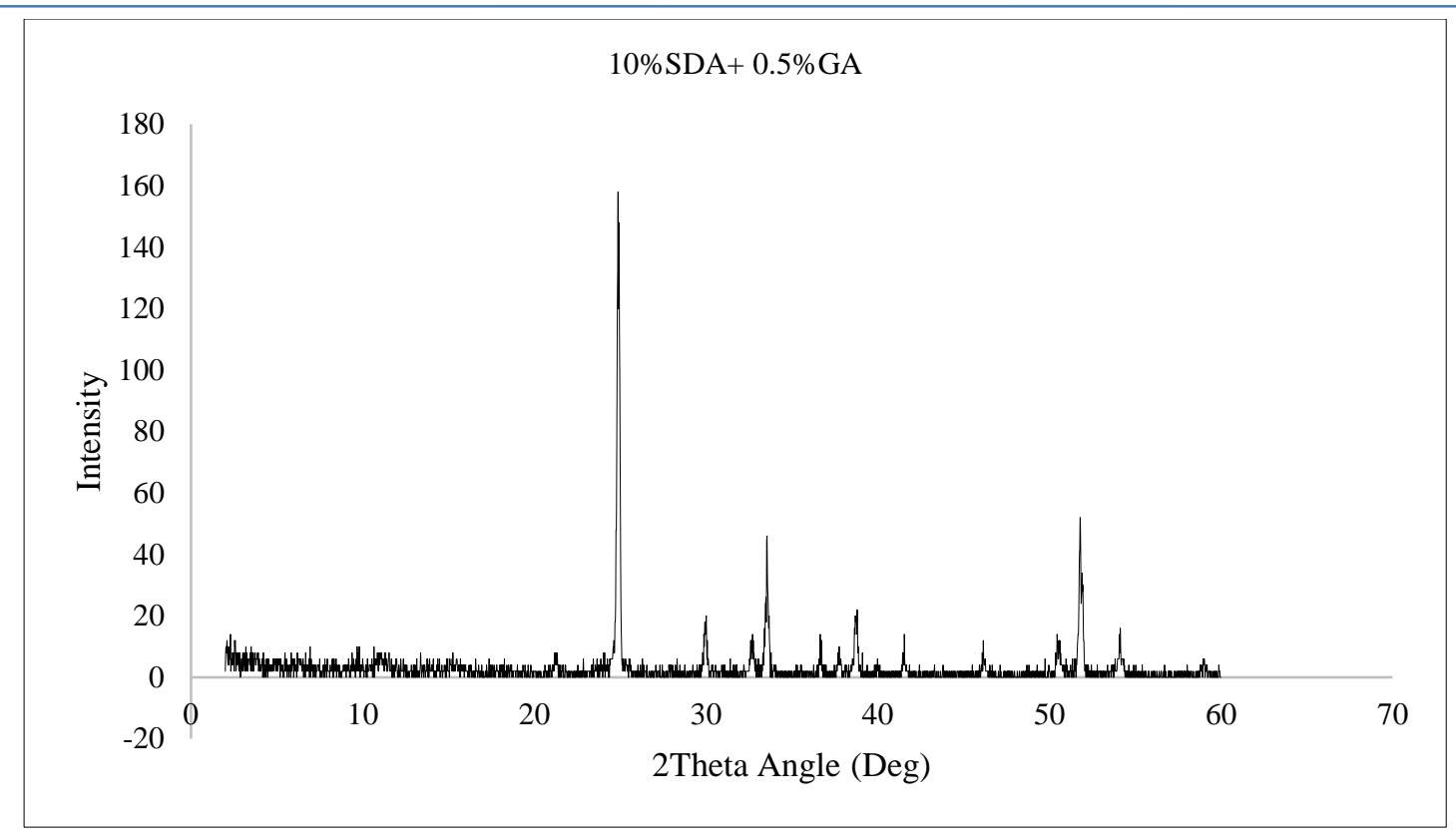

Figure 5: X-Ray Diffractogramme $10 \%$ SDA and $5 \%$ GA Concrete (M-10SDA/0.5GA)

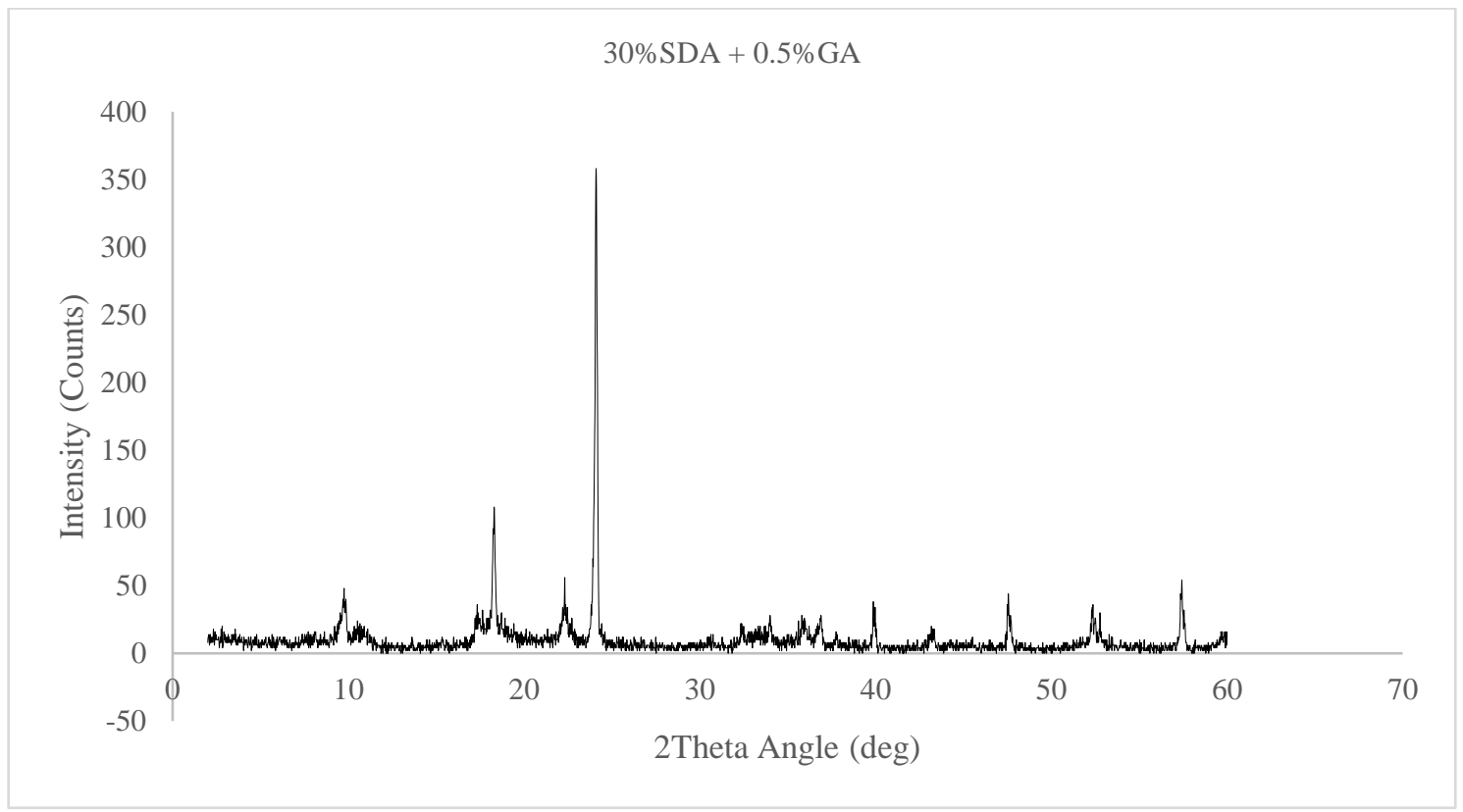

Figure 6: X-Ray Diffractogramme $30 \%$ SDA and $5 \%$ GA Concrete (M-30SDA/0.5GA)

The peaks of XRD at various angles of 2Theta are shown in Table 9. Figure 3 (Mix M-00SDA/GA) shows the three diffractogramme peaks occurring at 23.90, 24.05, and 47.55 degrees with corresponding intensities of 100, 31 and 20, respectively. The second mix, Figure 4 (M-00SDA/0.5GA) which contains no SDA but contains $0.5 \%$ GA has the peaks at 24.05, 18.27, and 9.8 degrees and intensities of 100, 13 and 6, respectively. The third and Fourth (Figurse5 and 6), which are M-10SDA/0.5GA; M-30SDA/0.5GA contain $10 \%$ and $30 \%$ of sawdust ash in addition to the $0.5 \%$ GA dosage respectively. These have their peaks at 24.88, 51.79, 33.54/24.09, 18.27, and 57.42 and intensities of 100, 38, 27/100, 24 and 16, respectively. The mineral elements found in the crushed samples are shown in Table 10. This table shows the hydration and phase developments that have taken place in the concrete mixtures. There are three principal forms of serpentine in the XRD data, lizardite, antigorite and chrysolite- all with approximate 
Augustine U. Elinwa, J. Mod. Mater.; Vol. 8, Issue 1, pp: 12-29, 2021

composition $\mathrm{Mg}_{3} \mathrm{SiO}_{5}(\mathrm{OH})_{4}$. Serpentine is reported to be likely present in the form of lizardite or chrysolite at low $\left(<300^{\circ} \mathrm{C}\right)$ temperature and at higher temperature phase, antigorite is prevalent at more than $300^{\circ} \mathrm{C}$ [23].

Table 9: Strongest Three (3) Peaks of the X-Ray Diffractogramme

\begin{tabular}{cccccccc}
\hline Mix No & $\begin{array}{c}\text { Strongest } \\
\text { Peak } \\
\text { No }\end{array}$ & $\begin{array}{c}3 \\
\text { Peaks } \\
\text { 2Theta } \\
\text { (deg) }\end{array}$ & $\begin{array}{c}\mathrm{d} \\
(\AA)\end{array}$ & $\boldsymbol{I} / \boldsymbol{I I}$ & $\begin{array}{c}\text { FWHM } \\
(\mathrm{deg})\end{array}$ & $\begin{array}{c}\text { Intensity } \\
\text { (Counts) }\end{array}$ & $\begin{array}{c}\text { Integrated } \\
\text { Int } \\
\text { (Counts) }\end{array}$ \\
\hline M- & 4 & 24.05 & 3.70 & 100 & 0.155 & 299 & 2270 \\
00SDA/GA & 3 & 23.90 & 3.72 & 31 & 0.093 & 93 & 585 \\
\hline M- & 10 & 47.55 & 1.91 & 20 & 0.126 & 59 & 420 \\
\hline 00SDA/0.5GA & 7 & 24.05 & 3.70 & 100 & 0.143 & 272 & 2247 \\
M- & 4 & 18.27 & 4.85 & 13 & 0.191 & 36 & 419 \\
10SDA/0.5GA & 10 & 24.88 & 3.58 & 100 & 0.193 & 100 & 1043 \\
\hline & 20 & 51.79 & 1.76 & 38 & 0.153 & 38 & 300 \\
M- & 13 & 33.54 & 2.67 & 27 & 0.151 & 27 & 244 \\
30SDA/0.5GA & 9 & 24.09 & 3.49 & 100 & 0.141 & 246 & 1992 \\
& 5 & 18.27 & 4.85 & 24 & 0.168 & 59 & 577 \\
\end{tabular}

Table 10: Summary of Minerals Identified in X-Ray Diffraction Test

\begin{tabular}{|c|c|c|c|c|}
\hline S/No & Control Mix & Mix with GA & Mix-10SDA-GA & Mix-30SDA-GA \\
\hline 1 & Xonotlite & Chrysolite & Halloysite & Phlogopite \\
\hline 2 & Lizardite & Hematite & Clinochlore & Antigorite \\
\hline 3 & Chrysolite & Phlogophite & Quartz & Chrysolite \\
\hline 4 & Albite & Magnesite & Wollostonite & Cristobalite \\
\hline 5 & Osumulite & Antigorite & Chrysolite & Antigorite \\
\hline 6 & Nepheline & Illite & Orthoclase & Osumulite \\
\hline 7 & Phlogopite & Osumulite & Hematite & Albite \\
\hline 8 & Witherite & Sepiolite & Nacrite-2 & JAWE \\
\hline 9 & Clinochlore & Albite & Sepiolite & (Chrysolite \\
\hline 10 & Illite & Witherite & - & Biotite \\
\hline 11 & Quartz & Quartz & - & Witherite \\
\hline 12 & Muscovite & Talc-2 & - & Illite \\
\hline 13 & - & - & - & $\begin{array}{l}\text { Sepiolite } \\
\text { Vesuvianite }\end{array}$ \\
\hline
\end{tabular}

XRD peaks indicate the presence of minerals shown in Table 10. It is evident that from Table 9 both GA and SDA samples showed distinct differences in peak intensities when compared with the control samples. The peak intensity reduced from 2270 counts for the control sample (M-00SDA/GA) to 2247 for M00SDA/0.5GA, thus representing a reduction of $1.01 \%$. The low value for this reaction is tied to the $\mathrm{pH}$ value of GA which is 4.0. Subsequently, the reductions of other mixes, M-10SDA/0.5GA and M30SDA/0.5GA (1043 and 1992 counts), are $54.05 \%$ and $12.24 \%$, respectively. The developments in these mixes containing SDA can be attributed to the partial destruction of silicate mineral structure including quartz due to high $\mathrm{pH}(>.10)$ in the lime treated SDA [24]. The transformations observed with the $10 \%$ and $30 \%$ of sawdust ash replacements, are due to the pozzolanic nature of SDA. SDA goes into secondary reaction with $\mathrm{Ca}(\mathrm{OH}) 2$ and thus usurping the calcium hydroxide present to produce C-S-H. This pozzolanic reaction is absent from the mix containing GA only (approx. 1\%). The concentrations of hydration process are determined through the length intensity of $\mathrm{Ca}(\mathrm{OH})_{2}$ and C-S-H collected by X-ray scans recorded as intensity counts. These are detected at several locations along the 2 Theta. A comparison of patterns clearly showed that the intensity of $\mathrm{CH}$ peaks representing $\mathrm{Ca}(\mathrm{OH})_{2}$ was significantly reduced 
Mechanical Strengths of Sawdust-Ash-Admixed Gum Arabic Concrete

with the increase in the SDA/cement ratios, i.e. 54.05\% for $10 \%$ SDA/Cement and $12.24 \%$ for $30 \%$ SDA/Cement, respectively. This further confirms that the maximum replacement for cement by wt. $\%$ of $\mathrm{SDA}$ is $10 \%$. The reaction of $\mathrm{Ca}(\mathrm{OH})_{2}$ with SDA is termed a secondary reaction. A reaction that prevents the reaction of $\mathrm{Ca}(\mathrm{OH})_{2}$ with atmospheric $\mathrm{CO}_{2}$ by usurping the $\mathrm{Ca}(\mathrm{OH})_{2}$. This is called carbonation which is responsible for reinforcement rusting [6].

\subsection{Numerical Equation-Mechanical Strength}

The mechanical strengths taken from Table 6 can be represented by a general equation given as Eqn. (1).

This is a general form of equation of a polynomial regression analysis package in Minitab 18 Software:

Where,

$$
y=a+b x+c x^{2} \quad \ldots .1
$$

$y=$ the response variables, in this case are:

Compressive strength $\left(f_{c}\right)$, flexural strength $\left(f_{r}\right)$, and splitting tensile strength $\left(f_{s t}\right)$

$a=$ the constant

$b, c=$ are coefficients

$x=$ age of the concrete samples

The correlation factors $\left(\mathrm{R}^{2}\right)$ of these equations show good interaction of the mix which ranged from $67 \%$ to $100 \%$ with their p-values as shown in Table 11 . Figures $7-9$ are plots taken at $10 \%$ replacement by wt. $\%$ of cement and $0.5 \% \mathrm{GA}$, for the compressive strength, flexural strength, and splitting tensile strengths, respectively. These replacements and dosage were established as optimum for SDA and GA in previous works $[4,1]$.

Table 11: Empirical Equation for SDA-GA Concrete

\begin{tabular}{|c|c|c|c|c|c|c|c|}
\hline \multirow{4}{*}{ Parameter } & \multirow{3}{*}{ Mix } & \multicolumn{6}{|c|}{ Empirical equation } \\
\hline & & \multicolumn{6}{|c|}{ Variable/Coefficient } \\
\hline & & Const & $\mathrm{X}$ & $X^{2}$ & STD & $\mathrm{R}^{2}$ & $\mathrm{P}$-value \\
\hline & M-00SDA/GA & 17.2 & 0.37 & -0.003 & 1.6713 & 94 & 0.059 \\
\hline \multirow{3}{*}{$\begin{array}{l}\text { Compressive Strength } \\
\left(\mathbf{k N} / \mathbf{m}^{2}\right)\end{array}$} & M-00SDA/0.5GA & 20.6 & 0.32 & -0.003 & 1.808 & 90 & 0.101 \\
\hline & M-10SDA/0.5GA & 12.2 & 0.32 & -0.003 & 1.065 & 96 & 0.037 \\
\hline & M-30SDA/0.5GA & 9.8 & 0.05 & - & 0.6878 & 90 & 0.014 \\
\hline \multirow{4}{*}{$\begin{array}{l}\text { Flexural strength } \\
\left(\mathbf{k N} / \mathbf{m}^{2}\right)\end{array}$} & M-00SDA/GA & 4.9 & 0.01 & -0.0001 & 0.1117 & 84 & 0.156 \\
\hline & M-00SDA/0.5GA & 5.0 & 0.01 & -0.0001 & 0.1338 & 67 & 0.332 \\
\hline & M-10SDA/0.5GA & 4.8 & 0.004 & negligible & 0.0093 & 100 & 0.001 \\
\hline & M-30SDA/0.5GA & 3.8 & 0.029 & -0.0002 & 0.2999 & 81.4 & 0.184 \\
\hline \multirow{4}{*}{$\begin{array}{l}\text { Splitting Tensile } \\
\left(\mathbf{k N} / \mathbf{m}^{2}\right)\end{array}$} & M-00SDA/GA & 0.98 & 0.03 & -0.0003 & 0.1918 & 91 & 0.086 \\
\hline & M-00SDA/0.5GA & 1.61 & 0.02 & -0.0001 & 0.0728 & 98 & 0.009 \\
\hline & M-10SDA/0.5GA & 1.02 & 0.02 & -0.0001 & 0.0682 & 99 & 0.013 \\
\hline & M-30SDA/0.5GA & 0.75 & 0.01 & -0.0001 & 0.1250 & 94 & 0.010 \\
\hline
\end{tabular}




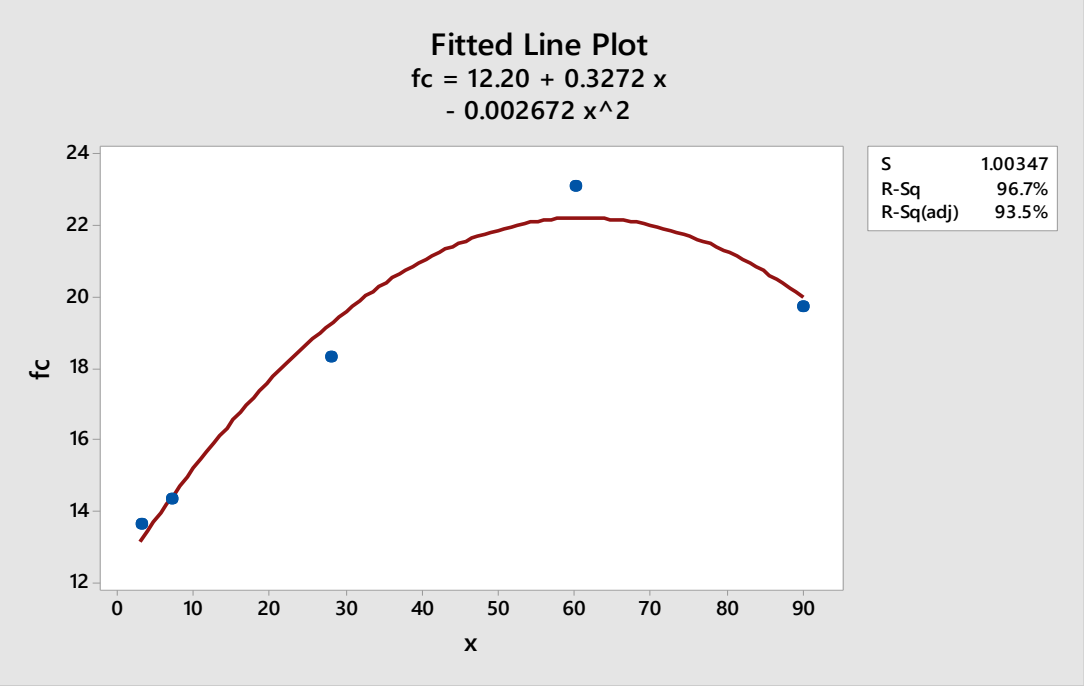

Figure 7: Compressive Strength of SDA-GA Concrete at $10 \%$ Replacement

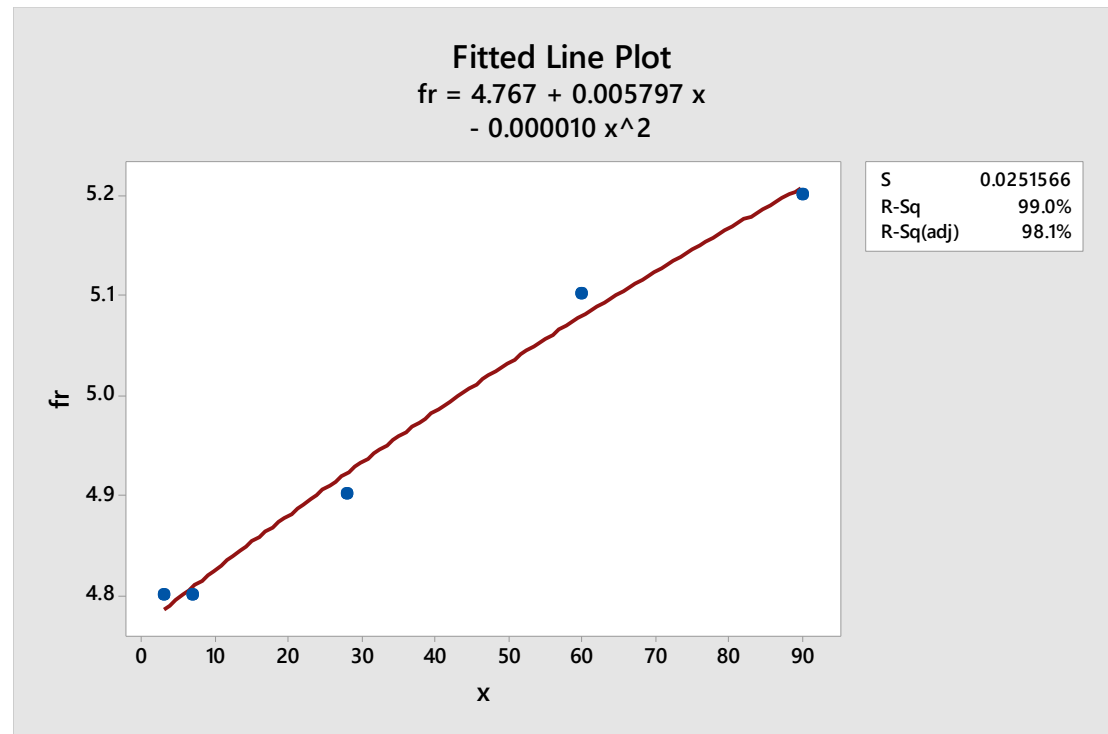

Figure 8: Flexural Strength of SDA-GA Concrete at $10 \%$ Replacement

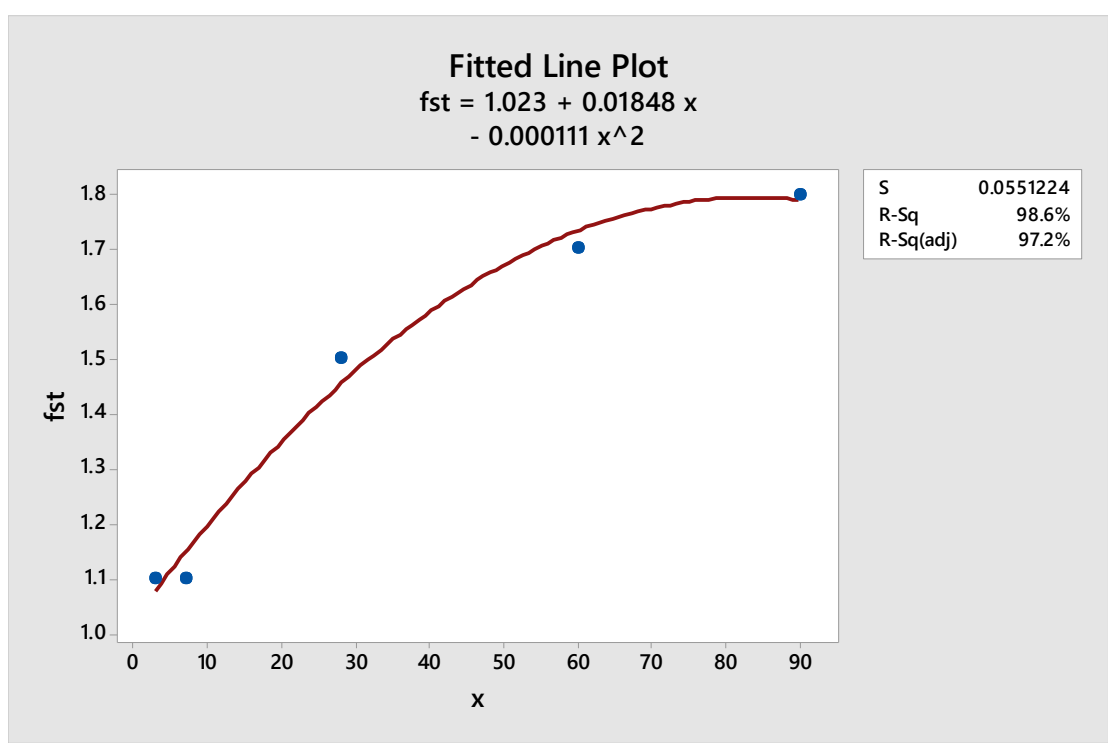

Figure 9: Splitting Tensile Strength of SDA-GA Concrete at $10 \%$ Replacement 
Mechanical Strengths of Sawdust-Ash-Admixed Gum Arabic Concrete

\subsection{Derivation of the Model Result}

The model data in Table 12 are derived by substituting the experimental data (Table 6) into the empirical equation (1) together with the derived coefficient from them (Table 11). These are carried out using the mix that has M-10SDA/0.5GA which was established as optimum from previous works. The fitness of these predicted values are further evaluated for error parameters, relative predictive errors (RPE), to know the goodness of fit of the predicted equations also shown in Table 12, determined using equation (2) [19, 25]:

$$
R P E=\frac{1}{n} \sum_{k=0}^{n}\left[\frac{f^{\prime}}{f}-1\right]^{2} \ldots .2
$$

Where $f$ is the experimental value (taken from Table 6 ) and $f^{\prime}$, the predicted value. The proposed equations provide good correlation when compared with the experimental. The statistical parameters for these proposed equations are shown in Table 13 for the compressive strength, flexural strength and the splitting tensile strength.

Table 12: Mechanical Strength-Relation of SDA-GA-Concrete

\begin{tabular}{|c|c|c|c|c|c|}
\hline & Mix No & Expt. & Model & $/ / f$ & RPE \\
\hline \multicolumn{6}{|l|}{ Parameter } \\
\hline \multirow{20}{*}{$\begin{array}{l}\text { Compressive Strength } \\
\left(\mathrm{kN} / \mathrm{m}^{2}\right)\end{array}$} & \multirow{5}{*}{ M-00SDA/GA } & 17.9 & 18.3 & 1.02 & \multirow{5}{*}{0.002} \\
\hline & & 19.2 & 19.6 & 1.02 & \\
\hline & & 26.7 & 25.2 & 0.94 & \\
\hline & & 27.4 & 28.6 & 1.04 & \\
\hline & & 28.0 & 26.2 & 0.94 & \\
\hline & \multirow{5}{*}{ M-00SDA/0.5GA } & 20.2 & 21.5 & 1.06 & \multirow{5}{*}{0.005} \\
\hline & & 23.5 & 22.7 & 0.97 & \\
\hline & & 28.6 & 29.3 & 1.02 & \\
\hline & & 28.8 & 29.0 & 1.01 & \\
\hline & & 29.2 & 25.1 & 0.86 & \\
\hline & \multirow{5}{*}{ M-10SDA/0.5GA } & 13.6 & 13.2 & 0.97 & \multirow{5}{*}{0.008} \\
\hline & & 14.3 & 14.3 & 1.00 & \\
\hline & & 18.3 & 18.8 & 1.03 & \\
\hline & & 23.1 & 20.6 & 0.89 & \\
\hline & & 19.7 & 16.7 & 0.84 & \\
\hline & \multirow{5}{*}{ M-30SDA/0.5GA } & 9.3 & 10.0 & 1.08 & \multirow{5}{*}{0.003} \\
\hline & & 10.6 & 10.1 & 0.95 & \\
\hline & & 11.1 & 11.2 & 1.01 & \\
\hline & & 13.4 & 12.7 & 0.95 & \\
\hline & & 13.6 & 14.1 & 1.05 & \\
\hline \multirow{10}{*}{$\begin{array}{l}\text { Flexural Strength } \\
\left(\mathrm{kN} / \mathrm{m}^{2}\right)\end{array}$} & \multirow{5}{*}{ M-00SDA/GA } & 4.8 & 4.9 & 1.02 & \multirow{5}{*}{0.001} \\
\hline & & 5.0 & 5.0 & 1.00 & \\
\hline & & 5.2 & 5.1 & 0.98 & \\
\hline & & 5.2 & 5.1 & 0.98 & \\
\hline & & 5.3 & 5.0 & 0.94 & \\
\hline & \multirow{5}{*}{ M-00SDA/0.5GA } & 4.9 & 5.0 & 1.02 & \multirow{5}{*}{0.001} \\
\hline & & 5.2 & 5.0 & 0.96 & \\
\hline & & 5.2 & 5.2 & 1.00 & \\
\hline & & 5.3 & 5.2 & 0.98 & \\
\hline & & 5.3 & 5.1 & 0.96 & \\
\hline
\end{tabular}


Augustine U. Elinwa, J. Mod. Mater.; Vol. 8, Issue 1, pp: 12-29, 2021

\begin{tabular}{|c|c|c|c|c|c|}
\hline & \multirow{5}{*}{ M-10SDA/0.5GA } & 4.8 & 4.8 & 1.00 & \multirow{5}{*}{0.002} \\
\hline & & 4.8 & 4.9 & 1.02 & \\
\hline & & 4.9 & 5.1 & 1.04 & \\
\hline & & 5.1 & 5.3 & 1.04 & \\
\hline & & 5.2 & 5.6 & 1.08 & \\
\hline & \multirow{5}{*}{ M-30SDA/0.5GA } & 3.6 & 3.9 & 1.08 & \multirow{5}{*}{0.003} \\
\hline & & 4.3 & 4.0 & 0.93 & \\
\hline & & 4.4 & 4.5 & 1.02 & \\
\hline & & 4.8 & 4.9 & 1.02 & \\
\hline & & 4.8 & 4.9 & 1.02 & \\
\hline \multirow{20}{*}{$\begin{array}{l}\text { Splitting Tensile } \\
\left(\mathrm{kN} / \mathrm{m}^{2}\right)\end{array}$} & & 1.0 & 1.1 & 1.1 & \multirow{5}{*}{0.034} \\
\hline & & 1.2 & 1.2 & 1.0 & \\
\hline & M-00SDA/GA & 1.9 & 1.6 & 0.84 & \\
\hline & & 1.9 & 1.7 & 0.89 & \\
\hline & & 2.0 & 1.3 & 0.65 & \\
\hline & \multirow{5}{*}{ M-00SDA/0.5GA } & 1.6 & 1.7 & 1.06 & \multirow{5}{*}{0.005} \\
\hline & & 1.8 & 1.7 & 0.94 & \\
\hline & & 2.0 & 2.1 & 1.05 & \\
\hline & & 2.3 & 2.5 & 1.09 & \\
\hline & & 2.4 & 2.6 & 1.08 & \\
\hline & \multirow{5}{*}{ M-10SDA/0.5GA } & 1.1 & 1.1 & 1.00 & \multirow{5}{*}{0.006} \\
\hline & & 1.1 & 1.2 & 1.09 & \\
\hline & & 1.5 & 1.5 & 1.00 & \\
\hline & & 1.7 & 1.9 & 1.10 & \\
\hline & & 1.8 & 2.0 & 1.10 & \\
\hline & \multirow{5}{*}{ M-30SDA/0.5GA } & 0.7 & 0.8 & 1.14 & \multirow{5}{*}{0.073} \\
\hline & & 0.9 & 0.8 & 0.89 & \\
\hline & & 1.2 & 1.0 & 0.83 & \\
\hline & & 1.3 & 1.0 & 0.77 & \\
\hline & & 1.6 & 0.8 & 0.50 & \\
\hline
\end{tabular}

The experimental and model data derived from Table 12 are thus plotted for validation, and this gives a relationship between the Modal data and Experimental data. This is represented by a general equation of the form:

$$
y_{1}=a+b x_{1} \quad \ldots .2
$$

$y_{1}=$ the response variables for the model, in this case, compressive strength $\left(f_{c}\right)$, flexural strength $\left(f_{r}\right)$, and Splitting tensile strength $\left(f_{s t}\right)$

$$
\begin{aligned}
& a=\text { the constant } \\
& b=\text { the coefficient } \\
& x_{1}=\text { experimental data of the concrete samples }
\end{aligned}
$$

These relationships are given as Figures 6 to 8 and their characteristics are shown in Table 13. They show high correlation factors of $86 \%$ to $96 \%$, and the model representations are equally significant $(0.022$ to $0.003)$.

Table 13: Sawdust Ash-Gum Arabic Prediction Model Characteristics

\begin{tabular}{ccccrr}
\hline \multirow{2}{*}{ Response variable } & \multicolumn{2}{c}{ Prediction variable (Expt) } & \multicolumn{2}{c}{ Model characteristics } \\
\cline { 2 - 6 } & Constant & Slope & STD & $\begin{array}{c}R^{2} \\
(\%)\end{array}$ & $\begin{array}{c}p \text { value } \\
\text { valury }\end{array}$ \\
\hline Model $f_{c}$ & 3.82 & 0.72 & 1.3094 & 86 & 0.022 \\
\hline Model $f_{r}$ & 3.43 & 1.73 & 0.0778 & 96 & 0.004 \\
\hline Model $f_{s t}$ & 0.20 & 1.21 & 0.0842 & 96 & 0.003 \\
\hline
\end{tabular}




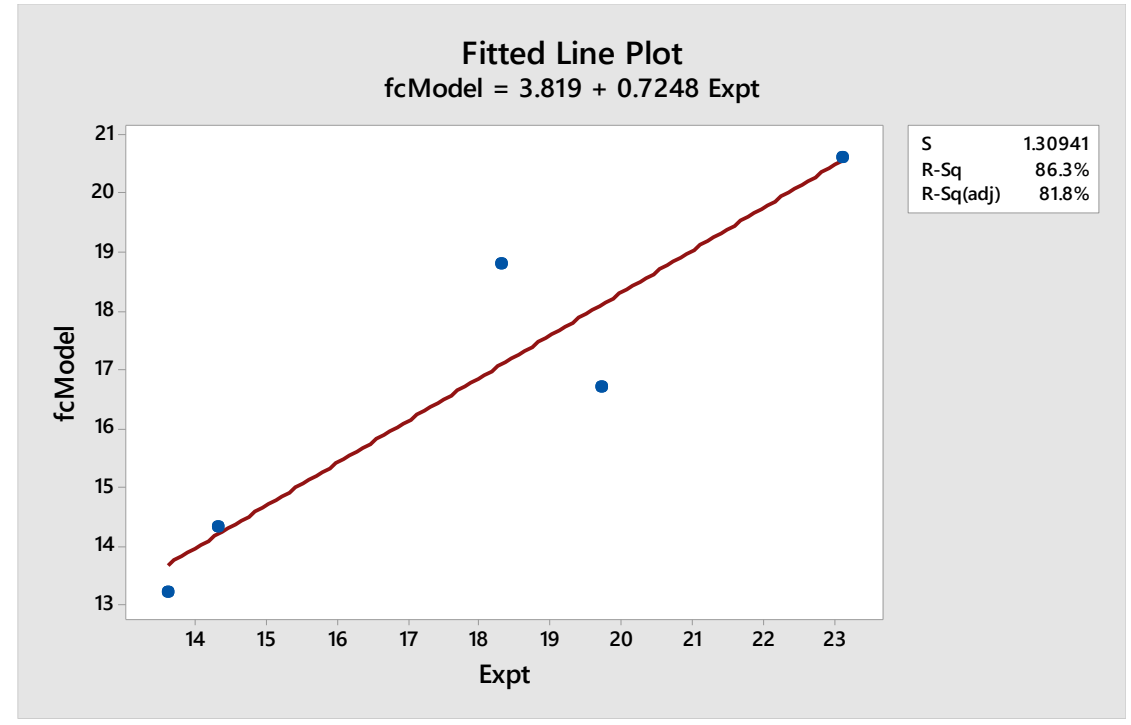

Figure 6: Experimental Data against Model Data at $10 \%$ Replacement

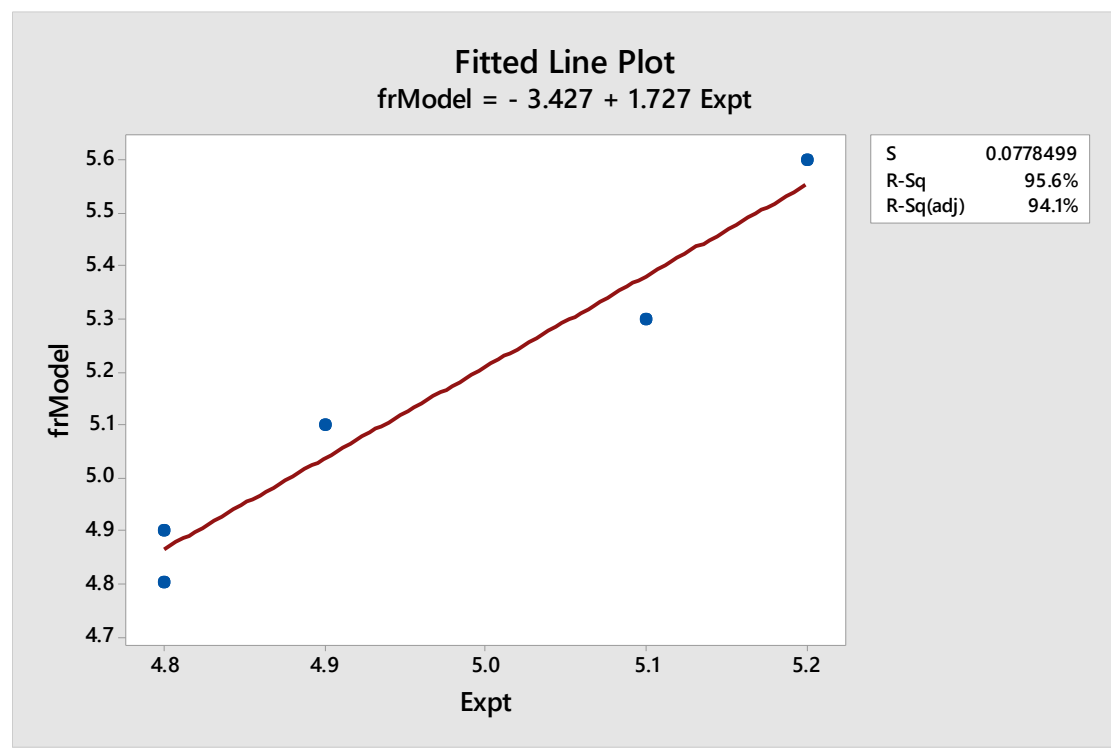

Figure 7: Experimental Data against Model Data for Flexural Strength at $10 \%$ Replacement

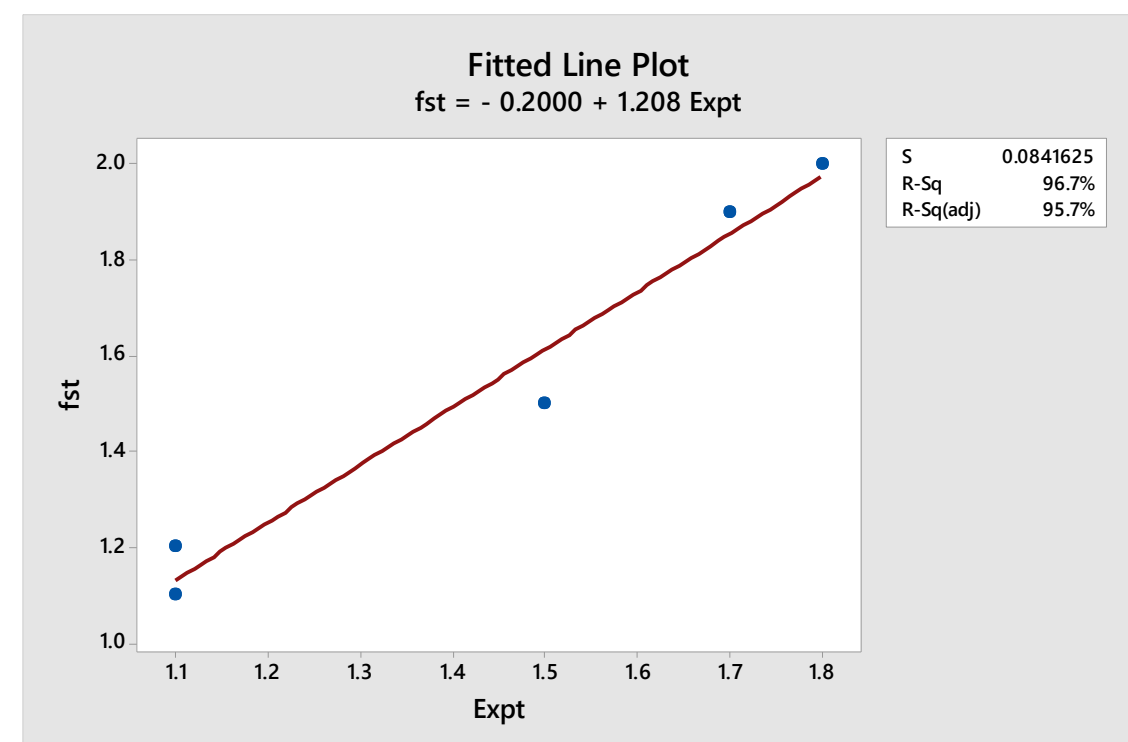

Figure 8: Experimental Data against Model Data for Splitting Tensile Strength at $10 \%$ Replacement 


\section{Conclusion}

The study on the effects of GA and SDA on concrete have been carried out and the following are the conclusions from the work. The use of GA and SDA will produce good quality concrete whose optimum replacement of SDA was confirmed at $10 \%$ by the XRD peak results. The peak intensity counts showed that the $\mathrm{Ca}(\mathrm{OH}) 2$ was reduced by $54 \%$ and $12 \%$ at $10 \% \mathrm{SDA}$ and $30 \% \mathrm{SDA}$, respectively. However, at this level of replacement and dosage of $0.5 \%$, the mechanical strengths of the GA-SDA concrete decreased. It is therefore, recommended that the use of a plasticizer may be required to further improve the mechanical strengths. This behavior of the mechanical strengths was represented by polynomial regression equations which are very significant with a relative predicted error (RPE) that is very insignificant. The two-third strength ratio at 28-days used for conventional concrete for stripping the formwork may not be appropriate for use when pozzolanic concretes are considered. This is because of delays in attaining the required design strength at the age of 28 days. Therefore, the work has proposed taken this at an age beyond 28 days of curing. This will carter for the pozzolanic effects of such materials like SDA which starts gaining strength well above 28 -days. In the same vein, the formwork stripping is proposed for the $60^{\text {th }}$ day of curing. This has also been factored into determining strength factors for flexural/compressive, splitting tensile/compressive, and splitting tensile/flexural strength for pozzolanic concretes. These are $0.27,0.08$ and 0.37 , respectively. Further confirmation on the characteristics of GA is required either as a retarder or an accelerator. It is also important to confirm the strength factor for formwork stripping. For supplementary cement materials.

\section{Competing Interests}

There is no conflict of interest in this work.

\section{How to Cite this Article:}

A. U. Elinwa, "Mechanical Strengths of Sawdust-Ash-Admixed Gum Arabic Concrete", J. Mod. Mater., vol. 8, no. 1, pp. 1229, Jun. 2021.

\section{References}

[1] Elinwa AU, Umar M. (2017). "X-ray diffraction and microstructure studies of gum Arabic-cement concrete. Construction and Building Materials, 156, 632-638.

[2] Elinwa, AU; Hazzard, MA (2017). "Effects of gum Arabic admixture on the mechanical strengths of cement paste and concrete." Advancements in Materials, 1, 25-39.

[3] Elinwa, AU; Abdulbasir G; Abdulkadir G (2018). "Gum Arabic as an admixture for cement concrete production." Construction and Building Materials, 176, 201-212.

[4] Elinwa, AU; Mahmood Y (2002). "Ash from timber waste as cement replacement materials." Cement and Concrete Composites, 24 (2), 219-222.

[5] Elinwa, AU; Mamuda, MA (2014). "Sawdust ash as powder material for self-compacting concrete containing naphthalene sulfonate." Advances in Civil Engineering, 2014, 8 pages.

[6] Elinwa AU, Abdulkadir S. (2011). "Characterizing sawdust ash for use as an inhibitor for reinforcement corrosion. New Clues in Science, 1, 1-10.

[7] BS EN 196-3 (2005). Methods of testing cement. Determination of setting time and soundness.

[8] BS EN 1097-6 (2013). Tests for mechanical and physical properties of aggregates. Determination of particle density and water absorption.

[9] Siddique R, Singh M, Singhal AK (2019). "Use of unprocessed wood ash as partial replacement of sand in concrete." ACI Materials Journal, 116 (6), 77-86.

[10] Raza, MS; Rai, K; Kumar, D; Ali, M (2020). "Experimental study of physical, fresh-state and strength parameters of concrete incorporating wood waste ash as a cementitious material.” Journal of Material and Engineering Structures, 7, 267-276.

[11] ASTM C31/C31M-19a (2019). Standard practice for making and curing test specimens.

[12] BS EN-12390-5 (2000). Method for determination of flexural strength.

[13] ASTM C78/C78M (2018). Standard test method for flexural strength of concrete (Using simple beam with third-point loading).

[14] C. Zhao, Q. Zhao, Y. Zhang, M, Zhou (2015). "The effect of gum Arabic on the dispersion of cement paste, in: F. Dong (Eds.), Proceedings of 11th International Congress for Applied Mineralogy (ICAM), 2015, pp. 483-494.

[15] R. Mbugua, R. Wanjala, J. Ndambuki (2015). "Influence of gum acacia karroo on some mechanical properties of cement mortars and concrete." Int. J. Civ. Environ. Struct. Constr. Architect. Eng. 9 (11) (2015) 2135-2139.

[16] Mohamamed AM, Osman MH, Smaoui H (2016). "Effect of Arabic gum biopolymer on fresh and hardened concrete properties." IJCSE, 6 (3), 187-194. 
Mechanical Strengths of Sawdust-Ash-Admixed Gum Arabic Concrete

[17] Oni DO, Mwero J, Kababo, C (2019). "Experimental investigation of the physical and mechanical properties of cassava starch modified concrete." The Open Construction and Building Technology Journal, 13, 331-343.

[18] Akamme Shiori, Iha Sakiko, Yamada Yoshitomo, Hosokawa Yoshifumi (2012). "Basic study on viscosity change process of cement paste by flocculation and hydration." Cement Science and Concrete Technology, 66 (1) 653-662.

[19] Elinwa, Augustine and Kabir, Nasir (2019). "Flexural strength and compressive strength relations of hospital waste-ash-concrete. SSRN: https://ssrn.com/abstract=3309506.

[20] Elinwa AU, Kabir Nasir (2019). "Flexural strength and compressive strength relations of spent foundry sand concrete. ACI Materials Journal, 116, (6), 205-211.

[21] Légeron F, and Paultre P (2014). "Prediction of modulus of rupture of concrete." ACI Materials Journal, 5, 76-82.

[22] ASTM D3906-03 (2008). Standard Test Method for Determination of Relative X-ray Diffraction Intensities of FaujasiteType ZeoliteContaining Materials.

[23] Evans, BW., Johannes, W., Oterdoom, H., Trommsdorff, V. (1976). "Stability of chrysorite and antigorite in the serpentine multisystem. Schwett, Mineral, Petrogr. Mitt., 56, 79-93.

[24] Hueste, M. B.; Chompreda, P.; Trejo, D.; Cline, D. B. H.; and Keating, P. B. (2004) "Mechanical Properties of High-Strength Concrete for Prestressed Member," ACI Structural Journal, 101, (4), 457-465.

[25] Pavan, A. and Dallas, NL (2020). "Analytical tests to evaluate pozzolanic reaction in lime stabilized soils." MethodsX, 7, 1-9.

Publish your research article in AIJR journals-

$\checkmark$ Online Submission and Tracking

$\checkmark$ Peer-Reviewed

$\checkmark$ Rapid decision

$\checkmark \quad$ Immediate Publication after acceptance

$\checkmark$ Articles freely available online

$\checkmark \quad$ Retain full copyright of your article.

Submit your article at journals.aijr.org
Publish your books with AIJR publisher-

$\checkmark \quad$ Publish with ISBN and DOI.

$\checkmark$ Publish Thesis/Dissertation as Monograph.

$\checkmark$ Publish Book Monograph.

$\checkmark$ Publish Edited Volume/ Book.

$\checkmark$ Publish Conference Proceedings

$\checkmark \quad$ Retain full copyright of your books.

Submit your manuscript at books.aijr.org 